\title{
The Relationship among Age and Parity with the Incidence of Hypertension in Pregnant Women in Grinting Village, Bulakamba Sub-District, Brebes Regency
}

\author{
Susy Sriwahyuni ${ }^{1 *}$, Darmawan ${ }^{1}$, Lili Eky Nursia $\mathbf{N}^{1}$, Arif Iskandar ${ }^{1}$, Khairunnas ${ }^{1}$ \\ ${ }^{1}$ Fakultas Kesehatan Masyarakat, Universitas Teuku Umar, Jl. Alue Peunyareng, Meulaboh-Aceh Barat 23615, Indonesia
}

\section{A R T I C L E I N F O}

IAKMI IPHJI use only:

Received date : 7 April 2020

Revised date : 25 April 2020

Accepted date : 27 May 2020

Keywords:

Age

Parity

Hypertension

Pregnant Women

\begin{abstract}
A B S T R A C T
Pregnant women are classified into groups that have a high risk during pregnancy until postpartum. One of the causes is hypertension in pregnancy. Factors of hypertension in pregnancy are age and parity. The purpose of the study was to determine the relationship among age and parity with the incidence of hypertension in pregnant women. This study used observational analytic method with cross-sectional approach. The number of samples taken by purposive sampling that were 49 pregnant women. The results of this study were relationship among age with $p$ value $=0.0002(\mathrm{PR}=2.440,95 \% \mathrm{CI}=1.004-6.559)$ and parity with $p$ value $=$ $0.0001(P R=2.33595 \% C I=1.0033,-5.446)$ with incidence of hypertension. The pregnant women with age $>35$ years and parity 1 times have a 2,880 chance of experiencing hypertension, compared with age $<35$ years and parity 1 . Base on the results of multivariate analysis Age is the most dominant determinant ( $p$ value $=0.000 \mathrm{CI}=1.224-22.432,95 \%$ ) with the incidence of hypertension. Intensive counselling regarding pregnant women is needed, especially for wife and husband to increase knowledge them.
\end{abstract}

(c) 2020 IAKMI Indonesian Public Health Journal. All rights reserved

\section{INTRODUCTION*}

Pregnant women are a group that has a high risk during pregnancy until post-delivery, this is because complications can occur at any time, before pregnancy, during pregnancy, and after pregnancy itself. Complications that often arise in pregnancy in general such as preeclampsia, high blood pressure (hypertension), abortion, gestational diabetes and anemia.

Hypertension in pregnancy is one of the causes of maternal death [1]. According to the World Health Organization (WHO) hypertension in pregnancy is one of the complications in pregnancy, in 2017 hypertension in pregnancy shows as a leading indicator of maternal mortality in the world of 810 people die every day. Meanwhile, according to the results of

\footnotetext{
* Corresponding author.

E-mail address: susysriwahyuni@utu.ac.id
}

research by the International Federation of Gynecology and Obstetrics (FIGO) states that hypertension in pregnancy is one of the contributors to the mortality rate of pregnant women amounting to 70,000 pregnant women die annually or equivalent to the ratio of maternal mortality 216 per 100,000 live births [2].

MMR in Indonesia experienced a decrease during the $1991-2015$ period, in 1991 MMR in Indonesia amounted to 390 / 100,000 live births to 305 / 100,000 live births in 2015 . According to performance data of the Ministry of Health of Republic of Indonesia 2015-2017 period showed a decrease in the number of maternal death cases, in 2015 there were 4,999 cases of MMR, in 2016 it became 4,912 cases, and in 2017 it decreased significantly to 1,712 cases [3].

According to Indonesia's health profile in 2015 the percentage of hypertension in 
pregnancy was $27.1 \%$, this percentage shows the number two cause of maternal death after bleeding cases as much as $30.3 \%$. (3) Hypertension in pregnancy affects about $10 \%$ of total pregnant women worldwide, diseases and conditions that include preeclampsia, eclampsia, chronic hypertension, and gestational hypertension [4].

Hypertension in pregnancy is a vascular disorder that occurs before pregnancy or arises in pregnancy or in the puerperium, is characterized by hypertension and is often accompanied by proteinuri, edema, convulsions, coma, or other symptoms. Diagnosis of hypertension in pregnancy can be seen through blood pressure tests that show results $\geq 140 / 90 \mathrm{mmHg}$. Factors that can cause hypertension in pregnancy include, age under 20 years or above equal to 35 years, pregnancy for the first time (primigravida), parity and body mass index [5].

Age is an important part of reproductive status. Age is associated with an increase or decrease in bodily functions, thus affecting a person's health status [5]. Maternal age during pregnancy is one of the factors causing hypertension cases in pregnancy, pregnant women at the age of more than 35 years are more at high risk of developing hypertension complications in pregnancy than if pregnant at normal age around 20-35 years. Old age factors cause the risk of diseases that accompany age also increases as heart disease and cancer become greater [6].

Another factor that can cause hypertension in pregnancy is parity. Parity is the number of fetuses weighing more than or equal to 500 grams who have been born alive or dead, parity 2-3 is the safest parity in terms of maternal death. Parity one and high parity (more than three) constitute parity at risk of hypertension in pregnancy. Parity is divided into several classifications, primipara: giving birth for the first time, multipara: having given birth more than once, and gande multipara: having given birth more than five times. In primigravida hypertension can occur in pregnancy because in the beginning the uterus is empty without a fetus then pregnancy occurs so that the mother's body adjusts especially when the placenta begins to form so that it can cause spasm of the arteries. in primipara there can be hypertension in pregnancy of about
$85 \%$ compared to multipara and multipara grande who experience hypertension in pregnancy by $15 \%$ due to too often the uterus is stretched during pregnancy [7].

The MMR in 2015 in Central Java Province was 611 cases, the number of cases was contributed by the Brebes health office as many as 52 cases out of 35 and in 2016 amounted to 163 / 100,000 live births or as many as 54 cases. Regencies in Central Java Province. The cause of maternal death in Central Java Province is hypertension in pregnancy as much as $26.34 \%$. Whereas based on monthly data from the Kluwut Public Health Center, the maternal mortality rate in 2016 was 4 cases per 963 per live birth. Maternal Mortality in the Kluwut Health Center is reported from Grinting Village due to hypertension in pregnancy [8].

The high cases of maternal mortality in Grinting Village have a close relationship with the incidence of hypertension in pregnancy. Risk factors that cause hypertension in pregnancy are complications that have been associated with maternal age $>20->35$ and parity 1 . So that in this study aims to determine the relationship of age and parity with the incidence of hypertension in pregnancy [9].

Based on preliminary studies conducted in Grinting Village, it can be seen from the results of blood pressure measurements of pregnant women at the Kluwut Community Health Center. Blood pressure checks on 10 pregnant women show that systolic blood pressure ranges from $110-190 \mathrm{mmHg}$ with an average of $150 \mathrm{mmHg}$. Whereas diastolic blood pressure shows the results of measurements ranging from $60-100 \mathrm{mmHg}$ with an average of $80 \mathrm{mmHg}$.

Based on the explanation above, the writer is interested in researching the Relationship between Age and Parity with the Occurrence of Hypertension in Pregnant Women in Grinting Village, Bulakamba District, Brebes Regency.

\section{METHOD}

The design study used observational analytic cross-sectional study design approaches, namely research conducted by taking a certain time that is relatively short and on time. This research will be observed without intervening between the independent variables 
and the dependent variable that is only find a relationship among the variables of age and parity with incidence of hypertension in pregnant women in Grinting village.

The study was conducted in the village of Grinting, Bulakamba District, Brebes Regency. Data collection by interview techniques, the number of the study were 49 pregnant women who were taken by purposive sampling. The analysis in this study uses bivariate and ChiSquare Tests.

\section{RESULTS AND DISCUSSION}

\section{Relationship between Age Hypertension in Pregnancy.}

The explanation in table 2 below can be seen from 49 pregnant women who became the study sample who had a "at risk" age that was clarified severely with the incidence of hypertension in pregnancy as many as 19 $(38.7 \%)$ and those who had no risk age were clarified mildly with the incidence hypertension in pregnancy by 10 (20.4\%).

Based on the results of Chi-Squre test, the $P_{\text {value }}$ obtained $<0.05$. These results indicate that there is a significant relationship between maternal age and the incidence of hypertension in pregnancy among pregnant women in Grinting village, the PR value $=2,440$, which means that respondents who have a "at risk" age with hypertension in high-risk pregnancy are at risk. 2 times suffer from hypertension in pregnancy when compared with age who are not at risk with the incidence of hypertension in pregnancy with mild clarification.

Table 1. The Relationship between ages with Incident of Hypertension in Pregnant Women

\begin{tabular}{|c|c|c|c|c|c|c|}
\hline \multirow[b]{2}{*}{ NO } & \multirow[b]{2}{*}{ Age } & \multirow{2}{*}{$\begin{array}{l}\text { Kejadian } \\
\text { Weight } \\
\text { N }(\%)\end{array}$} & \multirow{2}{*}{$\begin{array}{r}\text { Hipertensi } \\
\text { Light } \\
\mathbf{N}(\%)\end{array}$} & \multirow{2}{*}{$\begin{array}{l}\text { Jumlah } \\
\mathbf{N}(\%)\end{array}$} & \multirow[t]{2}{*}{$\overline{P \text {-Value }}$} & \multirow[t]{2}{*}{$\begin{array}{c}\text { PR } \\
(95 \% \mathrm{CI})\end{array}$} \\
\hline & & & & & & \\
\hline 1 & Risk & $19(38,7 \%)$ & $10(20,4 \%)$ & $29(100 \%)$ & \multirow{2}{*}{0,002} & 2,440 \\
\hline 2 & Not risk & $14(28,5 \%)$ & $6(12,2 \%)$ & $20(100 \%)$ & & $(1,004-6,559)$ \\
\hline & Amount & $33(67,3 \%)$ & $16(32,6)$ & $49(100 \%)$ & & \\
\hline
\end{tabular}

Mother's age is an important part of reproductive status. Age is related to the increase or decrease in bodily functions so that it affects a person's health status. The safest and best age for pregnancy and childbirth is 20-35. While adolescent women who are pregnant for the first time and women who are pregnant at the age of $>35$ years will be at risk for hypertension in pregnancy [11]. Risk factors for hypertension in pregnancy, one of which is the age at risk of experiencing hypertension, which is more than 35 years. This condition is inversely proportional to the age group too young or less than 20 years and age over 35 years is a predisposing factor for hypertension in pregnancy [12].
The results of research conducted by Ekasari, et al in 2018, the research showed there was a relationship between maternal age and incidence of hypertension in pregnant women [12]. Research conducted too by Tigor, et al. 2014 from the results of his study found that there was a significant relationship between age mothers with hyperensi occurrence in pregnancy [13].

According to the results of a study analyzed by Riskendas in 2013, it was stated that pregnant women who have age over 35 years are at risk for experiencing hypertension in pregnancy. Pregnant women aged $>35$ years have twice the chance to suffer severe hypertension in pregnancy. While pregnant women who have $<20$ years of age are at risk 
of developing hypertension in pregnancy. This is triggered because young age is an age group that does not yet have a mature mindset to make a decision that has the potential to experience hypertension in pregnancy [14].

\section{Relationship between Parity and the Occurrence of Hypertension in Pregnancy}

The explanation in table 3 below can be seen from 49 pregnant women who became the study sample who had a parity that had "multipara" with hypertension in a pregnancy which was classified as severe as 18 (36.7\%) whereas in parity that had "primipira" with the incidence hypertension in pregnancy with mild clarification of 9 (18.3\%).

Based on the results of Chi-Square test was pvalue $<0.05$. Obtaining significant results between maternal parity with incidence of hypertension in pregnancy. PR value $=2.335$ which means that respondents who have "multipara" parity with severe classification are at twice the risk of suffering from hypertension in severe pregnancy when compared with respondents who have "primipira".

Table 2. The Relationship between Parity with Incident of Hypertension in Pregnant Women

\begin{tabular}{|c|c|c|c|c|c|c|}
\hline \multirow[b]{2}{*}{ NO } & \multirow[b]{2}{*}{ Paritas } & \multicolumn{2}{|r|}{ Hypertention } & \multirow{2}{*}{$\begin{array}{l}\text { Jumlah } \\
\mathrm{N}(\%)\end{array}$} & \multirow[t]{2}{*}{ P-Value } & \multirow{2}{*}{$\begin{array}{c}\text { PR } \\
(95 \% \mathrm{CI})\end{array}$} \\
\hline & & $\begin{array}{l}\text { Berat } \\
\mathrm{N}(\%)\end{array}$ & $\begin{array}{l}\text { Ringan } \\
\mathrm{N}(\%)\end{array}$ & & & \\
\hline 1 & Multipara & $18(36,7 \%)$ & $9(18,3 \%)$ & $27(100 \%)$ & \multirow{2}{*}{0,001} & 2,335 \\
\hline 2 & Primipira & $15(30,6 \%)$ & $7(14,2 \%)$ & $22(100 \%)$ & & $(1,0033,-5,446)$ \\
\hline & Amount & $33(67,3 \%)$ & $16(32,6)$ & $49(100 \%)$ & & \\
\hline
\end{tabular}

\section{CONCLUSION}

Research results that have been explained are discussed. Then the conclusions were a significant relationship among maternal age $<20->35$ years and parity with incidence of hypertension in pregnant women in Grinting Village, Bulakamba District, Brebes Regency.

\section{ACKNOWLEDGMENT}

Thank you to the Head of Kluwut Health Center, Bulakamba Sub-District, Brebes Regency, who has helped in completing the research and the author of this article.

\section{REFERENCES}

[1] World Organization Health. Maternal Mortality. Maternal mortality ration $(M M R)=$ number of maternal deaths per 100,000 live births). (2017) Geneva. (https://www. who.int/reproductivehealth/publications/ maternalmortality-2000-2017. https://apps.who.int/iris/bitstream/handle /10665/329886/WHO-RHR-19.20eng.pdf?ua $=1$

[2] Sari, N Kartika, dkk. Determinan Gangguan Hipertensi Kehamilan di Indonesia. (2016) Vol.32 No.9. Berita Kedokteran Masyarakat (BKM Journal of Community Medicine and Public Health) https://www.researchgate.net/publication \$324117760 Kasus Hipertensi pada Keh amilan di Indonesia

[3] Kementerian Kesehatan Republik Indonesia. Profil Kesehatan Indonesia. (2017).

https://www.kemkes.go.id/resources/dow nload/pusdatin/profil-kesehatanindonesia/Profil-Kesehatan-Indonesiatahun-2017.pdf

[4] Imaroh, I Islahul, dkk. Faktor Risiko yang Mempengaruhi Kejadian Hipertensi Pada Ibu Hamil di Wilayah Kerja Puskesmas. Kedungmundu. (2017) Kota Semarang.Vol. 6 No.1. ISSN: 2356-3346. Jurnal Kesehatan Masyarakat (e-journa). 
https://ejournal3.undip.ac.id/index.php/jk m

[5] Sastrawinata S, et al. Obstetri Patologi IImu Kesehatan Reproduksi. (2005) Ed.2. Jakarta : EGC

[6] Ekasari T dan Natalia M Silvian. Deteksi Dini Preeklamsi dengan Antenatal Care. (2019) Sulawesi Selatan : Yayasan Ahmar Cendekia Indonesia

[7] Sinsin, L. Kesehatan Ibu dan Anak Masa Kehamilan dan Persalinan. (2008). Jakarta: Media Komputindo. ISBN: 978979-27-1509-5)

[8] Profil Dinkes Brebes. Dinas Kesehatan Kabupaten Brebes. (2016) Jawa Tengah.

[9] Prawirohardjo, S. IImu Kebidanan. (2010). Jakarta: PT Bina Pustaka. ISBN: 978-979-6150-25-8.

[10] Sujarweni W. Statistik Untuk Kesehatan. (2015). Yogyakarta: Gava Media. ISBN. 9786028545532
[11] Bobak et al. Keperawatan Maternitas. Ed.4. (2014). Jakarta : EGC

[12] Ekasari T, Natalia S.M. Deteksi Dini Preeklamsi dengan Antenatal Care. (2019). Sulawesi Selatan: Yayasan Ahmar Cendekia Indonesia. ISBN: 978-62392171-2-9.

[13] Sitimorang. N.T, Damantalm. Y, Januarita .A, Sukri. Faktor-faktor yang berhubungan dengan kejadian preeklamsia pada ibu hamil di Poli KIA RSU Anutapura palu. Jurnal Kesehatan tadulako. (2016).Volume 1. http://jurnal.untad.ac.id/jurnal/index.php HealthyTadulako/article/view/5744

[14] Riskesdas. Riset Kesehatan Dasar. Badan penelitian dan pengembangan Kesehatan Kementerian Kesehatan RI. (2013). Volume. 2. ISBN: 602235482X, 9786022354826. 
IAKMI Public Health Journal Indonesia

Volume 1 No 1 June 2020

Website : http://jurnal.iakmi.id/index.php/IPHJI

e-ISSN : 2722-550X 